\title{
Adolescents in Conflict with the Laws in São Paulo - Brazil: the Social Practices and Their Educational Processes
}

\author{
Willian Lazaretti da Conceição* \\ $\mathrm{PhD}$ Student in Education, University of Campinas, Campinas, Brazil \\ *Corresponding author: will_lazaretti@hotmail.com
}

Received July 02, 2014; Revised July 10, 2014; Accepted July 14, 2014

\begin{abstract}
This paper aims to present the specific educational services to adolescents who are under socio deprivation of liberty in the State of São Paulo - Brazil. The criminal liability of the young is by application of educational measures called that vary according to the severity of the offense and the ability of the young to fulfill it, with an education a right secured to this young man, regardless of offense. The qualitative research sought social practices of young offenders reported in theses and dissertations on specific topic, and the technique of classroom observation and informal conversations with the teachers, the period between 2008 and 2013 was also used. As a result, we found that formal education for these teens run as a space conquest of rights that were previously denied. Right attention, respect, acceptance, love, because the faculty deal with these teens with a look that recognizes them as subjects of rights and, in addition, comprise the peculiar developmental condition that pervade, understanding the anguish, doubts and behaviors sometimes inadequate.
\end{abstract}

Keywords: Brazil, education, adolescents offender, social practice, rights of children and adolescents

Cite This Article: Willian Lazaretti da Conceição, "Adolescents in Conflict with the Laws in São Paulo Brazil: the Social Practices and Their Educational Processes.” American Journal of Educational Research, vol. 2, no. 7 (2014): 559-563. doi: 10.12691/education-2-7-21.

\section{Introduction}

This paper aims to present the specifics of care to adolescents who are remanded in Foundation Center Customer Socio Adolescents ("Fundação CASA"), to fulfill requirements of rehabilitation and resocialization. This institution is responsible for implementing the measure on a semi-open regime and hospitalization for youth 12 to 21 years incompleted throughout the state of São Paulo.

For readability, we present the Brazilian scenario in the area of care for children and adolescents, emphasizing the rights regarding the accomplishment of the correctional and educational measures.

Historical analysis reveals that violence and devaluation when talking about children and young people are as old as the arrival of Europeans to Brazil, since children born to relationships between black people, Indians and white people were the fruit of violence, lack of dignity and expropriation of bodies. It was in this context that began to appear on Brazilian's ground the first rejected children, treated as objects and unattended [1].

Low income combined to the lack of jobs has occupied a prominent position among factors such as the lack of schools, health facilities and medicines. Even with government interventions that seek to offer and expand the social benefits that is not enough, it is necessary to create conditions that people could empower, especially those most affected by poverty [2]. With such inequality and lack of opportunity that promotes empowerment previously pointed out, families who are deprived of basic resources for subsistence eventually coalescing and forming "favelas" or as they are more recently called "communities" or "ghettos". As a theoretical choice, we use the term community when referring to low-income people living in the suburbs of large cities.

The juvenile trajectory is marked by processes of institutionalization, exclusion, violence, finally, the absence of welfare rights, as pointed studies [3,4,5]. Until the 80s, the practices of care for children and young people who commit crimes were marked by a correctional-punitive vision or a philanthropist-charitable vision. The enactment of the Statute of Children and Adolescents in 1990, brought a new way of dealing with the issue of youth in conflict with the law, establishing guidelines for determination off act and accountability of the young by their acts. The criminal liability of the young by applying educational measures that vary according to the severity of the offense and the ability of the young to fulfill it.

The social and historical construction of the rights for the infant-juvenile population that occurred in the twentieth century brings up significant impacts on social relations and cultural practices waged with children and adolescents who come to be recognized as subjects of rights from the Federal Constitution of 1988 and the 
enactment of the Statute of Children and Adolescents in 1990.

From this perspective, young population is admittedly composed by people in peculiar condition of development, thus providing a prospective value, which implies the conversion of the guaranteed of their rights to an absolute priority, affecting the perspectives on the organization of teaching practices, on the performance of educators and other factors involving the institutions of education [6].

And before they die of hunger or the need of other demands, when the family seeks for help, they face situations related to distortions and prejudices, and also with the lack of support, such as medical, educational and psychological services once available to those who can afford [7]. That inequality has generated several violent consequences among families, which directly affects the development of children who are raised on hostile environments involving violence, drug trafficking, corruption, prostitution and many other practices that corroborate their ingress on a misbehaviour atmosphere.

In Brazil each state is responsible for the implementation of educational detention measures and semi-freedom and they must follow the specifications granted on the National System of Socio-Educational Services Law [8], recent and specific law focus on youth who are in conflict with the law. That law has turned it mandatory that the Socio-Educational Assistance Plans of which state should include coordinated actions in the areas of education, health, social welfare, culture, job and sport training for young people in custody and they should clarify how these procedures will be completed. Thereby, the State Departments of Education have the responsibility to offer and ensure education for adolescents in situations of deprivation of liberty which some states have already developed, the state of São Paulo for instance.

So, the purpose of this study is to identify how the education of young people who are under educational detention occurs. Therefore, we use the technique of class observation and informal conversations with teachers in the period between 2008 and 2013.

\section{Students, Families, Teachers and their Relationships with the School}

Studies most recurring on this scene all concern about adults who are on restriction and deprivation of liberty, there are just a few studies dealing with children in conflict with the law and its relation to education. But, before the increase of law breakers minors, researchers from different areas start to search for reasons or aspects that contributed negatively to juvenile to commit unlawful acts.

Teenagers in custody are part of the impoverished population, the result of excluding economic models, which are displayed in the speeches of youth when referring to the practice of theft to may become consumers as well. In this context, the school becomes a setting for social meetings because the studying is not important before many adventures they plan to do after school hours which generally are not legally accepted.

These young people marginalized by society have many duties while they are in a situation of deprivation of liberty, and also some rights, such as receiving cultural activities, practicing sports, school activities and professionalization.
This right is the focus of this study, which we intend to present the peculiarities of the educational processes on school grounds.

Most children and adolescents admitted to rehabilitation units are males: 95\% are male and 5\% are women. Among men, the majority (about 70\%) have between 16 and 18 years. The second largest group are boys from 12 to 15 years. The age group with the highest dropout rate also has the highest number of internal systems and semi liberty(16-18 years). The offenses committed by young people who are in inpatient units and semi liberty are theft (38.1\% of cases), traffic (26.6\%) and homicide (8.4\%), according to the survey [26].

The school system used in the CASA Foundation has classes formed by students of different grades and planning is elaborated according with the State of São Paulo basis. This means that teachers have to teach to students of different grades and to adapt the subjects in the students and teachers books to the reality of the CASA Foundation, still considering the school delay of most teenagers and the different realities of each Center [11].

The measure of detention consists of principles that are complementary and are based on the premise that the educational process, in compliance of the measure, must consider brevity as a prerequisite. The teenager should not remain for long periods in custody, having in mind that the environment is constituted as dangerous because the practices and safety procedures of the multi routine confirm an imminent danger, to the servers and also for teenagers who experience a conflictual process of trying to protect against power relations that generate tension due the relationship between young people even if momentarily to an institution destined for dangerous individuals[9].

As Almeida mentions [9], there is a pedagogical concept, which is legitimate based in adolescent development because it considers the official purposes and intended effects of the detention centers, directing to a transformation or construction of a new life story based on the elaboration of the Individual Service Plan (ISP), which aims to outline the goals that adolescents should fulfill during and after suspension without disregarding their previous experiences.

One of the aspects that come with the systematization of the ISP is an analysis of how the teenager means the school context, seeking subsidies since the entry into the school environment, presents historical repetition as well as what possible grounds, curriculum components having affinity and that introduces lag, identified issues at the time of initial interview and diagnostic evaluation. It is an instrument that involves issues of reading, writing and mathematics, to which the adolescent must still be submitted in the first ten days of detention. Aims to identify the domain of competence in reading and writing, the ability to perform calculations and solve problems. From this assessment, teachers can know what level each adolescent is, facilitating individual student learning [10,11].

Most of the adolescents in conflict with the law are not in school, lack of interest caused by the difficulties that schools have to keep such students in classrooms, plus the use of drugs, change of city, work, pregnancy and diseases. Indeed it is not easy to develop educational activities with teens because of the large school delay [12]. 
For Dias [13] which sought to identify through interviews with youth in conflict with the law, which are the difficulties in school, involving the remaining in there. And the dialogue with the families of these young people identified that as adolescents, families also have a very low level of schooling, it usually went through very similar experiences, abandonment, poverty, exclusion and discrimination of different social markers.

These families need stimulation and conditions that guarantee access to school, even at advanced ages, firstly to ensure the pursuit of knowledge itself, and secondly, to encourage teenagers to study and attend classes regularly [13].

With this historical distancing of school space in their own family, students do not create links with the school and its actors and actresses, so routinely they feature not consistent with the actions that the school space allows. To what fits here, make a discussion of what is allowed or not, the objective is to highlight the transgression of the rules, since many schools have outdated rules that have been established but should be fulfilled.

Given the transgressions experienced by young people, many teachers give the logical sequence to exclude, take the problem out of the classroom, then the director removes the student from the school, and as if the problem ceased to exist, when in fact the problem is now in streets, in traffic, at traffic lights, child labor, crime and unable to learn and fight for their own rights as a citizen under development.

Although the school should provide the development of knowledge, ideas, attitudes and encourage behaviors that allow the effective incorporation in the civilian world, considering the freedom of consumer choice and political participation, and even responsibility in family life [16], you can ponder that this task is not being fulfilled, given the high number of young people who move away or are expelled from schools.

If the duty of the school is to socialize young people to respect the rules of society, how can we explain the exclusion suffered when they fail to follow all school rules, and some of these are authoritarian and meaningless, only to endorse the logic of oppressors and oppressed.

Paulo Freire [14] clarifies that the violence of the oppressors makes them also dehumanized, adopting the vocation of being less. The oppressed, in turn, sooner or later tend to retaliate against those who did the least. Often this is the first step for the students to become teenagers in conflict with the law, from deteriorating public equity, even practice Theft whom previously oppressed them.

Some time ago, the school employs various forms of punishment to students who are considered rebels, "when the school cannot 'cure' elements that threaten it, it starts to classify individual behaviors, indicating who is marginal, the slums, the placing "Maloqueiro" them the cause of disciplinary problems [15]. In other words, the social function of the school transcends socialization, and traces the path of standardization and disciplining, the most relevant educational processes revolve around the control of behavior.

These young stigmatized, marginalized are overwhelmed by a school that consolidates and transmits implicitly and explicitly an ideology that is based on individualism, competitiveness and the lack of solidarity, equality and formal valuation in accordance with the capabilities and individual efforts. Given this scenario, we consider that the social function of the school is being fulfilled, given that this institution is set up to develop the process of socialization, although not solely responsible for this task. That is, the family, social groups, the media also exert influence in this process, and so interconnected [16].

\section{Curriculum and Education Deprivation of Liberty}

Discuss curriculum issues in the contemporary is to organize more number of hours for each subject, the curriculum should not be understood as an innocent and disinterested neutral element of social transmission of knowledge, but rather as a full element of power relations that produces identities. On these power relations teenagers who abide by social measure of hospitalization, usually leave school early, accessing only the knowledge that others judge as basic for life. This knowledge is transmitted differentially at school, considering the different classes, namely: a vision appropriate to the world they were destined to dominate, other to those who were intended for subordinate social positions [17].

The curriculum and the culture dialogue constantly, you cannot conceive these two fields separately, and this culture in the curriculum is not one that is transmitted as a sure thing, but understood as a ground on which face different and conflicting conceptions of social life is that for which we fight and not what we received. But will the own teacher training have guidance for teachers to be able to promote multicultural spaces?

For a long period of time the culture was understood as a set of all that humanity had produced better, giving room for people who were considered educated or uneducated, or that a person had more culture than another, having as backgrounds cultural practices produced by the elite, because other things would be anything but the product of culture [18].

Any different "noise" in the unit, serves as the basis for the suspension of activities performed in the area of education [19]. For teenagers this reality is the opposite, because even after rebellions, teenagers have secured their pedagogical activities, deteriorated spaces are rapidly rebuilt for activities to be effective. Whereas participation in school social practice is characterized with one of the criteria that make up the goals of the individual plan of care for adolescents, being the school area one of the main one to the elaboration of reports which are forward to the judiciary.

The teachers have a curriculum to follow, but that does not reflect the reality in which they operate, for specific aspects of the socio educational care are not considered, such as security guards at the doors, the prohibition of the right to come and go, the prohibition use of basic school materials, but can offer risks, and all these issues imply perform various adaptations the contents and teaching strategies, and forms of assessment.

Such singularity of all shared experiences reinforces the conceptualization of the theory of teaching profession as a profession based on human interactions [20]. This is the assumption in the teacher education model underpinned by the epistemology of the practice, and it distinguishes 
from the technical rationality model in which the teacher works as a technician. In the epistemological model oriented to the practice, the teacher has been seen as an individual, and that justifies why researching altogether with individuals who research the (epistemology of their) practice.

Certainly to think of a curriculum for the environment of deprivation of freedom is a task of extreme complexity, because in addition to the content, so many other aspects must be considered, such as power relations, deprivation of freedom, discipline, oppression and stigmas [21].

Life in prison is dangerous since its daily routine is characterized by fear, by uncertainty and pain. The specifics of the prison institution, as discussed, are not few nor insignificant. Their peculiar characteristics favor the formation of a social system with values, norms and procedures that are appropriate to them. In this sense, it is argued that the form of organization of prisons and the relationships established by their subjects contributes to the settlement of the individual, since the primacy is given by adapting and not criticizing. The integration of the captive to society, accepting its rules and the internalization of values redound in suffering and even the supposed integration of its values in prison does not eliminate the exclusion; in contrast, emphasizes the weakness and the annulment of the individual [22].

Teachers need to think of what and how to teach, because education for those who are trapped is a 'key' law since it enables to other things, among them their rights, the recognition of themselves as subjects of rights [23]. But that power relationship between adolescents and institution some knowledge must be concealed, declining the most critical capacity and power or empowerment of adolescents.

It is possible to consider that the authority that teachers hold about adolescents is granted by young people themselves, and not by the imposition of the warden system, such as happens in public schools [24] Teachers establish relationships of respect and reciprocity which allows the young to speak, to expose and learn many things that previously could not among them how to talk, listen and dialogue with each other.

\section{Conclusion: Respect and Dialogue as a Way to be Achieved}

As results of this study, we showed that aspects such disrespect by some educators, learning difficulties, lack of interest and lack of stimulation of responsible, using and selling of drugs in the school environment weak the relationship between teenagers and school. In deprivation, learning difficulties remain, but the respect between teacher and student is the premise for the evaluation of both, and also because they are apart from the use/traffic of drugs, and for being on a more homogeneous class, they show greater interest in overcoming the difficulties, besides of having this assignment as an essential part in the process of discharged. After application of the measure of deprivation, the reality gets worst, considering the stereotype of marginal, many schools are resistant to accept them and that is why they get more and more distant from school.
Teachers do not have to work on specific deprivation training because it is during practice and by experience that you can learn the routine, languages and gestures that meets with the time that teenagers are living, in other words, the actions of teenagers can identify if they present intention or not to perform any riot or disorder.

School education for adolescents under social and educational detention in the CASA Foundation has moved in the direction to effect the speech to provide that the adolescent is the protagonist of his own life story. You can identify the guidelines forwarded by the School Management, which understands the difficulties that teachers and adolescents have and above all because they adopt a conception of education that overcome the banking education.

It is necessary to take actions that promote youth leadership, enabling the expression, reframing and construction of new practices anchored in autonomy and mutual commitment among educational institutions, seeking to overcome the production of school failure, and violence in school that sometimes entails the fulfillment of social and educational measures [24].

Men cannot free himself if he does not carry his history, if he does not take his existence on his hands. For the author the conscientization function of education is a process mediated by the encounter with the other [25].

Some obstacles arise from the partnership with the state Department of Education, the curriculum is part of the most complex aspects and it cannot move. We have pondered that it requires a specific curriculum for the Centers of Detention, to consider the peculiar demands of young people in situations of deprivation of liberty, namely: long time of leaving school, lag in the reader and writer skills, cognitive impairment arising from the use of illegal substances, lack of connection with the school due to multifactorial origins, such as lack of encouragement from family, disrespect of teachers and administrators, discrimination and etc.

However, teachers could be targeted regarding the differentiated work that has to be done, the institution has a school of Education and Professional Training, which could with the help of the professionals from the State Department of Education promotes opportunities for continuing education, providing time-sharing knowledge of lived experiences.

Educational processes arising from school social practice contribute significantly in the trajectory of these young people, however, as no one frees no one, it is up to teenagers themselves to reflect about their decision making. Formal education for these teens run as a space conquest of rights that were previously denied. Right attention, respect, acceptance, love, because the faculty deal with these teens with a look that recognizes them as subjects of rights and, in addition, comprise the peculiar developmental condition that pervade, understanding the anguish, doubts and behaviors sometimes inadequate.

It is possible to think about a childcare service marked in education where prevails the right to existence, dignity, recognition, freedom and participation in social life, collectively and publicly. It's all about possibilities and alternatives of a human existence, pronouncing the world and, than modify it [14].

It is certain that there will not be a proper, unified and standardized strategy because the educational practice, as 
well as all social practice, brings with it complexities and uniqueness by being specific human phenomena.

\section{References}

[1] Dias, A. F; Onofre, E. M. C. (2010) A relação do jovem em conflito com a lei e a escola. Impulso, Piracicaba, vol. 20, no. 49, 31-42. Available: https://www.metodista.br/revistas/revistasunimep/index.php/impulso/article/viewFile/870/471.[Accessed Mar. 2, 2014].

[2] Sen, A. Prefácio IN: Green, D.(2009). Da pobreza ao poder: como cidadãos ativos e estados efetivos podem mudar o mundo. (L. Vasconcelos Trad.) São Paulo: Cortez; Oxford: Oxfam International.

[3] Santana, J. S. S. O processo de exclusão de adolescentes no Brasil: sua origem na infância desvalorizada. (2000). In: Ramos, F. R. S.; Monticelli, M.; Nitschke, R. G. (orgs.). Um encontro da enfermagem com o adolescente brasileiro. Brasília: ministério da Saúde/ABEN Nacional, v. 1, p. 15-36.

[4] Lopes, R. E.; Silva, C. R.; Malfitano, A. P. S.(2006). Adolescência e Juventude de grupos populares urbanos no brasil e as políticas públicas: apontamentos históricos”. Revista HISTEDBR on-line, Campinas, n. 23, p. 114-130. Available

http://www.histedbr.fae.unicamp.br/revista/edicoes/23/art08_23.p df. [Accessed Mar. 10, 2014].

[5] Mendéz, E. G. (2006). Evolución histórica del derecho de la infância: ¿Por que uma historia de los derechos de la infância?. In: ILANUD; ABMP, SEDH, UNFPA (Orgs.). Justiça, adolescente e ato infracional. São Paulo: ILANUD.

[6] Passone E. F. K. (2014). "The New Actors of the Society in Social Policies of Attendance to the Children and the Adolescents in Brazil.” American Journal of Educational Research, vol. 2, no. 2, 97-101.

[7] Rizzini, I.; Rizzini, I; Naiff, L.; Baptista, R.(2007). Acolhendo crianças e adolescentes. $2^{a}$ Ed., São Paulo: Cortez; Brasília, DF: UNICEF; CIESPI; Rio de Janeiro, RJ: PUC-Rio.

[8] Brasil (2012). Lei $n^{\circ}$ 12.594, de 18 de Janeiro de 2012. Esta Lei institui o Sistema Nacional de Atendimento Socioeducativo (Sinase) e regulamenta a execução das medidas destinadas a adolescente que pratique ato infracional. Available: http://www.planalto.gov.br/ccivil_03/_Ato20112014/2012/Lei/L12594.htm

[9] Almeida, B. G. M. (2010). A experiência da internação entre adolescentes: práticas punitivas e rotinas institucionais. Dissertação (Mestrado em Sociologia). São Paulo: Universidade de São Paulo.

[10] Conceição, W. L. (2012). Lazer e adolescentes em privação de liberdade: um diálogo possível? Dissertação (Mestrado em Educação). São Paulo: Universidade Federal de São Carlos.

[11] Conceição, W. L. (2013). Escola e privação de liberdade: um diálogo em construção. Revista Brasileira Adolescência E Conflitualidade, 0 (9. Available:
http://periodicos.uniban.br/index.php?journal=RBAC\&page=articl e\&op=view\&path\%5B $\% 5 \mathrm{D}=430 \&$ path $\% 5 B \% 5 \mathrm{D}=402$. [Accessed Apr. 20, 2014].

[12] Gallo, A. E.; Williams, L. C. A. (2005). Adolescentes em conflito com a lei: uma revisão dos fatores de risco para a conduta infracional. Psicol. teor. prat., São Paulo, v. 7, n. 1, jun. Available : http://pepsic.bvsalud.org/scielo.php?script=sci_arttext\&pid=S151 6-36872005000100007\&lng=es\&nrm=iso $>$.[Accessed Apr. 13, 2014].

[13] Dias, A. F. (2011). O jovem autor de ato infracional e a educação escolar: significados, desafios e caminhos para a permanência na escola. Dissertação (mestrado em educação). São Paulo: Universidade Federal de São Carlos.

[14] Freire, P. (2005). Pedagogia do oprimido. 40 ed. Rio de Janeiro: Paz e Terra.

[15] Guimarães, A. M. (2003). Vigilância, punição e depredação escolar. Campinas: Papirus.

[16] Pérez-Gómez, A. I. (1998). As funções sociais da escola: da reprodução à reconstrução crítica do conhecimento e da experiência. In: Gimeno-Sacristán, J.; Pérez-Gómez, A. I. Compreender e transformar o ensino. Porto Alegre: Artmed.

[17] Moreira, A. F. B.; Tadeu, T. (2011). Sociologia e teoria crítica do currículo: uma introdução. In: Moreira, A. F.; Tadeu, T. Currículo, cultura e sociedade. São Paulo: Cortez.

[18] Veiga-Neto, A. (2003). Cultura, culturas e educação. Revista de Educação. no.23, maio/jun/Jul/Ago. Disponível em http://www.scielo.br/pdf/rbedu/n23/n23a01

[19] Leme, J. A. G. (2011). Analisando a "grade” da "cela” de aula. In: Lourenço, A. S.; Onofre, E. M. C. O espaço da prisão e suas práticas educativas: enfoques e perspectivas contemporâneas. São Carlos: EdUFSCar.

[20] Tardif, M. (2002). Saberes docentes e formação profissional. Petrópolis: Vozes.

[21] Santos, S. dos. (2011). O espaço administrado da prisão e a escola como locus de resistência. In: Lourenço, A. S.; Onofre, E. M. C. O espaço da prisão e suas práticas educativas: enfoques e perspectivas contemporâneas. São Carlos: EdUFSCar.

[22] Sykes, G. (1999). The society of captives: a study of a maximum prison. New Jersey: Princenton University Press.

[23] Scarfó, F. J. (2008). Los fines de la educación básica en cárceles en la provincia de Buenos Aires: el derecho humano a la educación. La Plata: Editorial Universitária de la Plata.

[24] Calado, V. A. (2010). Escolarização, gênero e conflito com a lei: um estudo de registros de atendimento a adolescentes em medida socioeducativa. Dissertação (Mestrado em Psicologia). São Paulo: Universidade de São Paulo.

[25] Fiori, E. M. (1986). Conscientização e educação. Educação e Realidade. Porto Alegre: UFRGS.

[26] Brasil (2013). Relatório da Infância e juventude - Resolução n. ${ }^{\circ}$ 67/2011: Um olhar mais atento às unidades de internação e semiliberdade para adolescentes. Brasilia: Conselho Nacional do Ministério Público. 